Flory, A. V. - Provocação formal em Heldenplatz

\title{
A literatura austríaca como questão para a historiografia literária alemã: a provocação formal em Heldenplatz, de Thomas Bernhard
}

\author{
Alexandre Villibor Flory ${ }^{1}$
}

\begin{abstract}
This article is composed by two different, though articulated, moments. First we intend to discuss some aspects of the difficulties related to literary historiography nowadays, by questioning the concept itself, as well as the difficulties in establishing a History of German Literature, when we consider some Austrian contemporary authors. After that, we discuss some aspects regarding the Austrian author Thomas Bernhard's last play, Heroes' Square (Heldenplatz), premièred in 1988. The whole process of writing and staging was marked by the author's design to cause an intentional scandal. As such, the very concept of the play involves its reception in a very fruitful dialectics between arts and society, and not resulting in a merely accidental provocation at the formal level. Thus, the play questions the very conception of art as something organic and self-enclosed, updating the brechtian epic tradition, decisive also for the development of the Brazilian theater, from the 50`s until the present day.
\end{abstract}

Keywords: Thomas Bernhard; German Literature; Literary Historiography; Critical Theory; Formal Provocation Aesthetics.

Resumo: Este artigo é formado por dois momentos distintos, porém articulados. Em primeiro lugar, pretende-se colocar algumas questões centrais para a discussão sobre a historiografia literária. Isso será feito tanto pelo questionamento de seu estatuto nos dias de hoje, bem como das dificuldades de se estabelecer uma história literária em língua alemã, quando se tem em vista autores austríacos contemporâneos. Num segundo segmento, a partir das considerações anteriores, iremos discorrer sobre a pertinência de uma perspectiva imanente. Para isso discutiremos alguns aspectos sobre a última peça do austríaco Thomas Bernhard, Praça dos Heróis (Heldenplatz), de 1988. Todo seu processo de escrita e encenação foi marcado por um escândalo programado pelo autor. Deste modo, a própria concepção da peça envolve a recepção em uma dialética entre arte e sociedade muito fecunda, resultando numa provocação elevada ao nível da forma, e não meramente acidental. Assim, questiona uma concepção de obra de arte orgânica e fechada, atualizando uma tradição épica decisiva.

\footnotetext{
${ }^{1}$ Doutor pela USP, professor de teoria literária da Universidade Estadual de Maringá (UEM). Email: alexandre_flory@yahoo.com.br
} 
Flory, A. V. - Provocação formal em Heldenplatz

Palavras-chave: Thomas Bernhard; Literatura Alemã (Teatro); Historiografia Literária; Estética da Provocação Formal.

\section{Questões atuais para a historiografia literária}

Um tema como Literatura alemã e sua historiografia aparentemente repousa sobre bases epistemológicas inquestionáveis, contando com uma tradição forte e sólida. Mas engana: já instaura uma relação entre literatura e história que, nos tempos que correm, volta a ser o palco de discussões acaloradas e, muitas vezes, pouco proveitosas, posto que colocada sob a perspectiva de uma primazia de um ou outro lado. Essa discussão se abre por diversas frentes. Para começar, a história como disciplina, e mais propriamente a escrita da história (historiografia) vê questionado seu estatuto científico no que diz respeito à sua pretensa objetividade documental. A perspectiva de onde se fala passa a fazer parte do estudo da história, e nesse sentido a historiografia ganha uma dimensão subjetiva com a qual tem que lidar. Noutro plano, quem é o sujeito da história, quando já se veem as condicionantes culturais, sociais, políticas e econômicas atuando como as forças determinantes do devir histórico? Essas questões valem também para a historiografia literária, e tocam o estatuto do autor literário, dos narradores e dos personagens na obra de arte.

Além disso, a escrita da história literária possui um objeto próprio, com seus problemas específicos. Ela passa pela determinação de quais são as obras mais significativas, de acordo com algum critério, seja ele o gosto pessoal, o peso da tradição, a lista dos mais vendidos, a inserção em um determinado movimento literário, o grau de inovação dos procedimentos, entre outros. Isso leva, necessariamente, à construção de um cânone literário que tem por guia uma base histórica. Não há, como no caso da história, o recurso a uma pretensa autenticidade pautada pela verossimilhança externa, ou seja, a um fato histórico. A crítica e história literárias precisam criar os fatos literários, por assim dizer, e lidar com o que poderia ter acontecido, o que difere em qualidade, não apenas em grau, do que efetivamente aconteceu.

A subsunção de obras literárias a um determinado movimento artístico ou estético pode eliminar, justamente, o que essas obras têm de próprio, restando, no mais 


\section{Flory, A. V. - Provocação formal em Heldenplatz}

das vezes, um arrefecimento de sua carga reflexiva, em virtude do ímpeto classificatório e homogeneizador, que tende a excluir o que não está previsto em suas prerrogativas teóricas.

A própria concepção de uma história literária implica a aceitação tácita de princípios do historicismo, que acompanha a linha do tempo e o preenche, de modo homogêneo, com algumas obras, que acabam niveladas em termos de juízo estético. A objetividade aparente pode levar à homogeneização crítica e ao controle da obra pelo seu comentador - acompanhada, de praxe, por um breve estudo sobre a vida do autor, do período histórico em que viveu e de sua filiação estética, que servem como moldura em relação à obra, não se levando em conta suas correlações imanentes, da ordem da organização interna. Limita-se ao desenho de um plano geral. Mas essa falsa objetividade, com pretensões universalizantes, não prescinde de critérios valorativos e seletivos, nem sempre explícitos, pairando acima do plano geral da obra, como se fossem verdades atemporais e naturais.

Mais recentemente, a ascensão do campo dos Estudos Culturais colocou novas questões para a historiografia literária. Se um resultado palpável da historiografia é a elaboração de um cânone literário, como lidar com uma nova epistemologia que se apóia na diferença, na valorização e reconhecimento das culturas, no plural, e não na alta cultura, que antes era assumida como cultura tout court? Visto pelo prisma conservador, os estudos culturais vieram para destruir o valor da literatura, e seus articuladores formariam a Escola dos Ressentidos, na formulação do crítico Harold Bloom, autor do renomado O cânone Ocidental. (CEVASCO 2003: 138) Aceitando essa proposição - do fim do valor devido ao respeito exagerado pelas diversas culturas, inatacáveis - em que bases se sustenta uma história da literatura, até mesmo porque o conceito de literatura se amplia para abranger novos gêneros, inclusive o que antes era desprezado como de pouco (ou nenhum) valor estético?

Por fim, devemos considerar o debate instaurado pela estética da recepção que, na esteira da aula inaugural de Hans Robert JAUSS em 1967, intitulada A história da literatura como provocação à teoria literária (1994), também promove um redimensionamento da história literária ao compreender a literatura como um fenômeno e, assim, dependente da recepção de alguém para existir. A história da literatura será 


\section{Flory, A. V. - Provocação formal em Heldenplatz}

uma história da sua recepção, a partir dos contemporâneos e continuamente recolocada. No modelo tradicional, as mudanças na historiografia literária eram episódicas, refazendo o cânone e o redefinindo para, em seguida, cristalizá-lo. Nessa acepção, a mudança é prevista pelo sistema, mas está restrita a momentos específicos, como uma abertura fugidia e corretiva, pois o seu modo de ser em estado normal é o do sistema fechado, acabado e sincrônico. Assim, as mudanças pontuais visam um novo equilíbrio. Na proposta de Jauss - e isso é decisivo - a historiografia precisa encampar o processo de formação de uma dada literatura, de tal modo que consiga envolver a diacronia na sincronia: em primeiro plano está o processo. O seu modo de ser, o caráter ontológico dessa historiografia, postula a abertura e a indeterminação, resultando numa reescrita contínua da mesma.

\section{Algumas anotações sobre a literatura austríaca pós-1945}

O caso da literatura austríaca pós-1945 é muito pertinente para se discutir algumas questões referentes à escrita da história literária. Uma vertente que se tornou artisticamente dominante - por conta de sua articulação com esforços nos planos político e social, e não por seu suposto valor, como se verá - procurava, após a segunda guerra mundial, marcar as bases de uma literatura eminentemente austríaca, dentro do contexto maior da construção de uma identidade austríaca.

Mas antes disso, após a I. Guerra Mundial, a necessidade de se construir uma identidade nacional austríaca já estava posta e enfrentava obstáculos complexos. Para começar, o Império Austríaco no século XIX era formado por muitos povos (Vielvölkerstaat), não havendo espaço nem interesse para a criação de uma perspectiva nacional, temida pelo poder central do Império desde os tempos do Congresso de Viena, em 1815, por conta do seu potencial destrutivo: o nacionalismo faria ruir as bases deste Império de muitos povos, dividindo-os. Após a primeira guerra mundial, no entanto, o Império está extinto, e resta a dúvida pela viabilidade econômica da Áustria. Sem o parque industrial da Boêmia e as terras cultiváveis da Hungria, não eram poucos os que receavam pela sua capacidade de se estabelecer como nação autônoma. O receio, apesar

de infundado, teve efeitos diretos: levou a Áustria ao projeto de anexação com a 


\section{Flory, A. V. - Provocação formal em Heldenplatz}

Alemanha logo após a I. Guerra Mundial, em 1918, o que angariou amplo apoio popular e só não se efetivou por imposição dos países vencedores da guerra, que não desejavam uma Alemanha fortalecida após sua derrota. (STEININGER 1997: 99-152).

A Primeira República se estende de 1918 a 1934, ano que marca o início do Austrofascismo, na onda dos totalitarismos de direita que chegam ao poder em boa parte da Europa ao longo dos anos 30. A anexação com a Alemanha nazista ocorrerá apenas em 1938, quando as tropas alemãs invadem a Áustria sem qualquer sinal de reação, terminando em 1945 com o fim da II. Guerra Mundial, dando início à Segunda República. A anexação com a Alemanha complica o processo de criação identitária e cultural em andamento desde a Primeira República. Após 1945 a Áustria vivia outro contexto histórico e político, e o projeto de uma identidade austríaca iria se pautar por outras articulações: o Estado austríaco irá se posicionar frente às forças vencedoras (os aliados) na condição de "primeira vítima" de Hitler, com o quê alcançava dois objetivos de uma só vez: por um lado, facilitava a aceitação de sua própria conduta na guerra e, por outro lado, fazia parte dos esforços para se reconquistar a autonomia política, alcançada apenas em 1955, com o Contrato de Estado (Staatsvertrag). Uma tendência cultural oficiosa assume o espólio da rica tradição austríaca, procurando 'resgatar' uma cultura milenar. Desse modo se compreende o papel destacado da arte para a construção desta auto-imagem, tanto externa quanto internamente, absolutamente necessária no contexto configurado a partir da Segunda República.

Faz-se necessário acompanhar o desenvolvimento do campo literário para que possamos tecer considerações relativas à historiografia literária austríaca. No imediato pós-1945, não mais circulavam no cenário local nomes como Robert Musil, Karl Kraus, Hermann Broch, Joseph Roth e Stefan Zweig, entre outros autores de destaque antes da segunda guerra, seja porque faleceram ou porque não retornaram à Áustria do exílio. (MENASSE 2005: 139-40; SCHMIDT-DENGLER 1996: 20; ZEYRINGER 1999: 111)

Os autores que assumiram o primeiro plano na Áustria estavam alinhados com uma reconstrução literária conservadora, politicamente instrumentalizada para a elaboração de uma 'ideia austríaca', projeto esse que passava pela repressão e esquecimento do passado recente, linha que ficou conhecida como 'culturalismo representativo' (ZEYRINGER 1999: 119). “A “reconstrução” [econômica e política, AF] 


\section{Flory, A. V. - Provocação formal em Heldenplatz}

correspondia à reconstrução de uma literatura tradicional" (ZEYRINGER 1999: 111)² A política cultural oficial passará às mãos dos autores dessa vertente. Essa literatura tinha feição clássica, em estilo realista tradicional, por vezes idílico. Em termos políticos, posicionava-se contra o comunismo. Em termos estéticos, lutava contra as vanguardas e contra uma literatura crítica. Em termos históricos, não deveria enfrentar e discutir o passado recente.

Um escritor de relevância para essa vertente, Lernet-Holenia, afirma em artigo na revista Turm: "Nós devemos apenas continuar onde o sonho de um louco nos interrompeu. De fato não precisamos olhar para a frente, mas para trás. [...] nós somos [...] nosso passado" (apud SCHMIDT-DENGLER 1996: 22). Este olhar para o passado não procura dignificá-lo, mas apagá-lo. Advoga um salto para antes da guerra e para fora da história, em direção a uma tradição petrificada e recriada. O passado a que ele alude aspira à empatia com outro tempo: o espírito que anima este projeto é o do historicismo. Esta será a perspectiva oficiosa do imediato pós-1945, que culmina numa 'literatura do lar' (Heimatliteratur) idílica, voltando-se para a vida nas vilas, neo-biedermeier. $\mathrm{O}$ Estado austríaco encabeça e organiza essa remissão afetiva ao passado em várias frentes: sociais, políticas, culturais, mas esta última fica em destaque.

[...] no esforço de esquecer as consequências do passado nazista de alguns indivíduos estava unida a maioria dos partidos e, do mesmo modo, agiram também alguns autores que, agora, não se obrigavam a assumir a responsabilidade de se sentirem como a consciência da nação. (SCHMIDTDENGLER 1996: 22)

Mas essa perspectiva não era a única no panorama literário austríaco no período. Em torno do periódico Plan, organizado por Otto Basil, havia lugar para uma vanguarda estética e uma literatura crítica, que procuravam dar expressão ao passado recente por caminhos diversos. A Plan publicou textos de autoras como Ingeborg Bachmann e Ilse Aichinger, que figuram entre os criadores mais importantes desta época. Infelizmente a revista fecha as portas em 1948, inclusive por falta de apoio oficial. O livro de Aichinger Die größere Hoffnung (1948) é representativo desta literatura, discutindo a

\footnotetext{
${ }^{2}$ As traduções do alemão são de Alexandre Flory, salvo quando especificado.
} 


\section{Flory, A. V. - Provocação formal em Heldenplatz}

perseguição racista no totalitarismo, narrado sob o ponto de vista de uma criança. Há nestes autores um ceticismo renitente quanto à capacidade de expressão da linguagem, dada a vivência recente. Faltou, no entanto, a essa vanguarda uma recepção dentro da Áustria condizente com sua importância, recepção essa obtida na Alemanha, sobretudo no âmbito do Grupo 47 (ZEYRINGER 1999: p. 112-5). Para articular a importância estética e social dessa literatura com seu desprezo interno - instigado pelos que controlavam o sistema literário, da vertente anterior - era preciso fazer o caminho mais longo, saindo da Áustria. Internamente, Menasse atribui a esta revista (Plan) e aos autores que se opunham à versão oficiosa ${ }^{3}$ um papel decisivo para a compreensão da literatura da época na Áustria, mas em chave retrospectiva, pois ganha atenção a partir dos anos 1970, dada a falta de reverberação interna ainda no final dos anos 40 (MENASSE 2005: 138).

Além destas duas posições polarizadas, aqui apenas esboçadas, encontramos várias outras propostas num espectro bastante amplo. Porém, é um fato que os autores afastados do campo culturalista que não conseguiram êxito fora da Áustria tinham poucas possibilidades de serem publicados e lidos. Um autor que conseguiu firmar seu nome de modo indelével foi Heimito von Doderer, com romances muito importantes nos anos 1950. Embora tradicionalista, não se submetia à linha oficiosa, que estava empenhada na idealização de um passado austríaco heroico. Tampouco coaduna com a visão negativa e cética dos vanguardistas e críticos, defendida por jovens escritores. Acreditava na força harmonizadora e construtiva da literatura, divergindo da crítica da linguagem como aparece em Aichinger e Bachmann. Apesar disso, é um dos principais defensores dos grupos de vanguarda, como o Wiener Gruppe. Seus romances, como Die Strudlhofstiege (1951), são essenciais para a narrativa dos anos 50 na Áustria. Para Doderer, não teria ocorrido uma quebra histórica interna, como se viu na Alemanha, e,

\footnotetext{
${ }^{3}$ Embora essa vertente tenha lastro oficial, ao dominar a política cultural, não havia propriamente um documento que definisse as bases de uma estética oficial. Nada impediria, a rigor, que um expoente da vanguarda experimentalista assumisse um cargo em uma pasta da cultura. Na prática, porém, isso seria impossível. Daí a preferência pelo termo "oficioso" e seus correlatos, ao invés de "oficial".
} 


\section{Flory, A. V. - Provocação formal em Heldenplatz}

portanto, não haveria a necessidade de um recomeço do zero (Stunde Null) (AUCKENTHALER 1994: 155). ${ }^{4}$

A primeira tendência era dominante não por seu valor estético, mas por se alinhar (oficiosa- e oficialmente) à política de harmonização, proporção e de parceria que marcará a grande coalizão política que governou a Áustria até 1966, formada pelos dois grandes partidos da época, o SPÖ (Partido social-democrata austríaco) e o ÖVP (Partido do povo austríaco). Esses autores recebem subvenções do governo, cargos nos ministérios da educação, cultura e comunicação, são agraciados com prêmios, dominam as seções de cultura dos grandes jornais, em suma, controlam a administração da cultura no país e têm influência decisiva sobre o sistema literário, onde atuavam com mão de ferro. (ZEYRINGER 1999: 64-5)

Esse quadro muda pouco ao longo dos anos 1950, embora haja aumento gradual dos espaços para as vanguardas e para uma literatura crítica, como os cabarés literários do final dos anos 50, embora isto continuasse marginal em relação à administração da cultura do país. A revista Neue Wege publica obras de autores como Paul Celan e Ernst Jandl, entre outros que não seguiam a cartilha oficiosa. Nos anos 1960 surgem obras fundamentais como Das dreißigste Jahr (1961), de Ingeborg Bachmann, e Fasching (1967), de Gerhard Fritsch, narrativas nas quais o passado austríaco sob o nazismo é exposto sob outra perspectiva: a de sua continuidade aterradora e, portanto, de sua sobrevivência social, em termos de mentalidade e comportamento.

Nessas obras, questiona-se a recriação de um passado nazista sob o signo da vitimização. Esta é tomada como processo falso, repressor e duplamente perverso: quando os criminosos assumem a condição de vítimas, todos aqueles que os acusarem os que foram, efetivamente, vítimas durante o nazismo - são considerados criminosos, acusados por suposta difamação e calúnia, além de covardia. Esta a articulação precisa que surge, com toda a força, em um conto como Unter Mördern und Irren (escrito entre 1956-7), do livro já citado de Bachmann. O passado se torna uma acumulação de destruição e esmagamento contínuos, sem que se aprenda nada com ele. A certa altura,

\footnotetext{
${ }^{4}$ Nota-se uma diferença significativa com o quadro geral da literatura alemã, que, no imediato pós-guerra, tinha como uma de suas linhas de força elaborar artisticamente o envolvimento de milhões de pessoas nos crimes nazistas. (LÄMMERT 1995: 299)
} 


\section{Flory, A. V. - Provocação formal em Heldenplatz}

nesse conto, um dos personagens 'judeus' resume a história de sua família como uma sequência de atrocidades: "Meu pai foi vítima da Era Dollfuß [Austrofascismo, 19341938], meu avô uma vítima da monarquia, meu irmão vítima de Hitler." (BACHMANN 2005: 177)

Embora reprimido e latente, esse passado existe e se manifesta em situações específicas, dado que a repressão e o esquecimento forçado não o eliminaram, antes procuram justificá-lo. Em Fasching, a máscara do carnaval posta sobre a máscara social revela a feição efetiva, sem disfarces, de muitos de seus moradores. O personagem Felix Golub, que salvara a cidade ao final da segunda guerra da devastação travestido de mulher após abandonar o front de batalha e fugir, precisa se esconder para não ser linchado por aqueles que salvou. Agora, doze anos depois, esconde-se no mesmo cubículo onde ficara confinado ao desertar, evidenciando, alegoricamente, uma afinidade atroz entre os dois momentos históricos ali aproximados - 1945 e 1957. Em um final narrado como fluxo de consciência, Felix já não consegue distinguir as duas épocas, que formam uma e a mesma atrocidade.

Como se pode ver por estes dois exemplos, trata-se de um enfrentamento do passado recente que se realiza tanto no plano formal como no histórico, uma retomada e ressignificação do passado e do presente, numa atitude necessária e premente. As condições para tal altercação, no entanto, ainda não estavam maduras e, sintomaticamente, estas obras também ficarão sem a devida atenção e recepção no período em que foram publicadas. Foi preciso um tempo de quase 30 anos para que Fasching fosse relançado em 1995 e conseguisse a recepção que merecia. ${ }^{5}$

Nos anos 70 uma série de fatores contribuiu para mudar o cenário em definitivo. Os autores que administravam e controlavam a vida literária austríaca estavam ligados ao braço austríaco da PEN-Club, associação internacional de escritores formada em 1921 para unir forças em favor dos direitos humanos, ou seja, em origem uma organização apolítica. Mas ela se politiza em 1933, ao se posicionar contra a queima de livros feita pelos nazistas. Em sua seção austríaca, os autores ligados a ela eram os

\footnotetext{
5 Cf. MenASSE 2005: 223-4, sobre a fria recepção de Fasching; ZEYRINGER 1999: 130, sobre a fraca recepção do conto de Bachmann quando publicado.
} 


\section{Flory, A. V. - Provocação formal em Heldenplatz}

executores da política cultural tradicionalista: contra as vanguardas, contra os autores de esquerda e contra uma literatura crítica. Quando Heinrich Böll recebe o prêmio Nobel no início dos anos 70, Lernet-Holenia abandona a presidência da PEN-austríaca, como protesto por conta das ligações de Böll com a esquerda social-democrata alemã. No contexto desta crise, em 1973 surge outra associação de escritores, a GAV (Grazer Autorinnen Autorenversammlung), com os vanguardistas à frente. No mesmo ano de 1973 a GAV já recebe, também, financiamentos do governo, dividindo o bolo e o poder sobre a administração da vida literária com os membros da PEN. Além da crise desta instituição, cumpre acrescentar a influência do partido social-democrata (SPÖ), desde 1970 governando como partido único a Áustria, para uma mudança no quadro oficial. Sua nova política cultural via com bons olhos a quebra do monopólio dos autores da PEN. (INNERHOFER 1995: 234)

No âmbito do desenvolvimento do campo literário é importante comentar o embate entre autores de esquerda, em defesa de um realismo crítico (numa literatura empenhada, sobretudo formalmente, com nomes como Michael Scharang e Josef Haslinger), contra autores experimentalistas, em torno de nomes como Peter Handke e Alfred Kolleritsch (defendendo a autonomia do campo estético). Simplificando as posições em jogo para efeito do argumento: para Handke, os 'realistas' tomariam a palavra como espelho da realidade, o que seria falso; para os realistas os 'experimentalistas' voltavam-se para o 'eu' de forma escapista (LANDA 1995: 215-24). A síntese dialética destas posições - só em aparência antagônicas - ocorre com a cesura político-cultural nos anos 1980, nosso interesse maior neste artigo. No plano político, uma nova fase se consolida com a eleição de Kurt Waldheim para a presidência austríaca, provocando um escândalo em torno da descoberta e divulgação de sua participação nas forças SS nazistas. A este novo quadro político e social corresponde uma movimentação imediata no campo literário, em termos de produção, circulação e recepção; a dialética entre arte e sociedade ganha nova configuração (MILLNER 1995: 248-266). Para ZEYRINGER,

desde 1985/86 não há mais dúvida do significado político que os autores e seus textos podem ter (também) na Áustria, não apenas naquilo que está em primeiro plano, para ser lido diretamente com vistas às suas pretensões políticas, mas também pela crítica da linguagem como crítica social. (ZEYRINGER 1992: 101) 
Flory, A. V. - Provocação formal em Heldenplatz

Peter Handke consegue criar uma imagem muito expressiva deste momento decisivo, em que a articulação constitutiva entre arte e sociedade torna-se central, ao dizer que os anos 1980 na Áustria não entraria para a história como Era Waldheim, mas como Era Bernhard (apud SCHMIDT-DENGLER 1996: 6). Voltaremos a isso adiante.

\section{Histórias da literatura austríacas (e alemãs)}

Assim se tem um quadro rápido e simplificado da dinâmica do campo literário austríaco no pós-1945. A reconstrução operada no campo cultural pela vertente do 'culturalismo representativo' que controla a vida literária no imediato pós-1945 também se materializa na elaboração de histórias da literatura austríaca, afinadas com seus pressupostos. A volta às raízes será construída por uma série de historiadores literários, que ora regressam à Idade Média, ora ao barroco austríaco, quando Viena rivalizava com Paris como capital européia, ora param na Áustria Biedermeier da Era Metternich, na época do Congresso de Viena (1815).

No plano das histórias da literatura austríaca, esse processo de criação da identidade nacional já é visível na influência de um autor como Anton WILDGANS, que em sua Rede Über Österreich (1929) apresenta uma perspectiva nacionalista e ufanista da cultura austríaca e dos austríacos que serve de ponto de partida para boa parte da linha conservadora e regressiva da literatura austríaca a partir de 1945. Frases como "estamos trabalhando na construção (...) de uma Nova Áustria", firmada sobre "valores de uma cultura elevada e de uma humanidade especial", lembrando que fazemos parte "do que foi o terceiro maior reino em nossa Europa" (WILDGANs 1929), marcam seu texto e já deixam claro o que Lernet-Holenia tem em mente quando afirma que se deveria voltar as atenções para o passado anterior ao nazismo.

Outro autor decisivo para o período é Josef Nadler, que defende a continuidade e influência da tradição barroca, do século XVII e XVIII, para a literatura austríaca. Esse itinerário parte da contra-reforma católica, com o impedimento da entrada do protestantismo e da ilustração na Áustria. Sua base teórica de cunho positivista o faz 


\section{Flory, A. V. - Provocação formal em Heldenplatz}

conceber a história literária a partir de critérios como raça, lugar e momento histórico, posição que o aproximará dos nazistas e suas ideias de purificação da raça. No quarto volume de sua Literaturgeschichte des deutschen Volkes, de 1941, está a passagem famigerada que fala sobre a "extirpação dos judeus do corpo do povo alemão." (NADLER apud BERGER 1995: 193) Isso o fará perder a cadeira de professor de germanística em Viena, em 1945, em um caso de enorme repercussão. Apesar disso, de acordo com Zeyringer, será apenas no final da década de 1970 e início dos 1980 que se dará a "lenta 'saída de cena' (Auslaufen) de uma geração de professores ainda parcialmente formada por Josef Nadler" (ZEYRINGER 1999, p. 21).

Outra perspectiva, também conservadora, foi estabelecida pelo italiano Claudio Magris. O título já diz muito: O mito habsburgo na literatura austríaca (1966). A estrutura básica deste 'mito' literário concebe a Áustria dos Habsburgos como uma época feliz, marcada pela medida e pela harmonia, expressão de uma Europa Central caracterizada pela ordem e organizada como um conto de fadas, no qual o tempo não corre tão depressa e se arvora em um depositório de valores seculares e eternos. Este 'mito Habsburgo' teria conseguido transformar a contraditória realidade austríaca em um mundo seguro e calmo.

O trabalho de Magris apóia-se em três pilares para erigir este 'mito': o universalismo (unindo a Europa Central), a burocracia (vinculada ao imobilismo dos valores) e o hedonismo (a entrega aos prazeres sensoriais face à impotência política). $\mathrm{O}$ imobilismo era assim revestido com significado profundo e elevado à revelação da mais alta sabedoria, enquanto era, de fato, apenas uma realidade dolorosa imposta pelas condições objetivas - uma, embora apreensível, sofrida realidade: assim limitações e erros passavam a vantagens e virtudes (MAGRIS 1988: 15). Ulrich Greiner publica, em 1979, um livro em que leva adiante as teses de Magris, entendendo as obras de Peter Handke e Thomas Bernhard como representantes máximos desta tradição do mito Habsburgo (GREINER 1979: 14s).

Embora Magris avalie criticamente a construção literária destes mitos e, portanto, não faça sua apologia, tanto ele quanto Greiner valorizam exageradamente as tradições literárias vinculadas ao conservadorismo, atribuindo espaço secundário para autores como Johann Nestroy e Ferdinand Raymond, como bem pontua Norbert Weber. 


\section{Flory, A. V. - Provocação formal em Heldenplatz}

Para este, o trabalho de Magris não leva em conta o campo estético como parte das atividades humanas, dando preferência a certos autores como representantes de um modelo pré-concebido de literatura - o que tem afinidades explícitas com o culturalismo representativo (WEBER 1980). Para Zeyringer, a paulatina diminuição da influência de Nadler será perniciosamente substituída pela imagem de Magris e Greiner de uma literatura austríaca escapista e conservadora. (ZEYRINGER 1999: 40)

Por fim, resta discutir a perspectiva a partir da qual SCHMIDT-DENGLER e Klaus ZEYRINGER concebem uma história literária austríaca, muito diferente das apresentadas até agora. A partir do início da década de 1990, os dois começam a tratar do tema por meio de dois encontros acadêmicos, que geraram dois livros de artigos compilando as comunicações mais importantes. O momento histórico e o contexto são decisivos: o enfrentamento do passado já opera em todos os níveis da sociedade, da política à economia, tendo a cultura papel preponderante, como já visto, participando diretamente da vida social por uma nova mediação entre literatura e sociedade. Esse quadro exigia uma nova perspectiva teórica e crítica para a literatura do período - e retrospectivamente sobre toda a história literária austríaca, para livrá-la de interpretações tradicionalistas das elites dominantes. Sem esse percurso, corria-se o risco de se perder esse momento-chave no fogo-fátuo do comentário literário, preso excessivamente ao rés-do-chão dos fatos brutos. A crítica tinha a função de alcançar o 'teor de verdade' dessa literatura (e sociedade) e dar expressão a ele. Esse esforço teórico precisava realizar a crítica da apropriação idealizada e falsa do passado, efetivada pelas correntes tradicionalistas, o que funciona como alicerce para o projeto de uma reescrita da história literária austríaca. Esse é o sentimento que anima o trabalho de Schmidt-Dengler e de Zeyringer.

Num artigo escrito a quatro mãos podemos encontrar os pontos principais do projeto conjunto, mas desenvolvido isoladamente (SCHMIDT-DENGLER; ZEYRINGER 1995). Levam em consideração que uma história literária ocupa, no âmbito dos estudos literários, uma posição de muito peso e força: qualquer neutralidade é enganosa. Portanto, seu caráter de construção deve ser evidenciado, assim como seus critérios de seleção. A base para uma história da literatura austríaca não deve ser a geografia, ou uma visada nacionalista e patriótica (uma 'ideia de Áustria'), nem mesmo a retomada de uma cultura milenar, ou a busca de um estilo de escrita eminentemente austríaco. Uma 


\title{
Flory, A. V. - Provocação formal em Heldenplatz
}

sequência de autores canônicos, de movimentos estéticos ou políticos, reserva pouca atenção às obras específicas. Essas propostas, em parte apresentadas acima, não podem servir, sozinhas, de base para um empreendimento como a escrita de uma história literária. Para eles,

\begin{abstract}
Literatura surge e está (inserida) num determinado contexto. Assim se configura para a história literária uma constelação específica de problemas: "como a literatura penetra nos processos históricos? (condicionada por eles, atuando sobre eles, interpretando-os) e como ela mesma pode ser descrita como processo histórico?" (MÜLLER apud SCHMIDT-DENGLER; ZEYRINGER 1995: 11)
\end{abstract}

Para conseguir tratar de um assunto tão complexo, eles preconizam estudar a função dos textos literários nos âmbitos social, político e histórico, em casos concretos, o que os leva a uma história social da literatura austríaca. Subjacente a este projeto, já desenvolvido em parte nas obras citadas nas Referências Bibliográficas deste artigo, está a necessária relação entre literatura e sociedade, que radica tanto nos temas quanto nas formas, sem deixar de lado as funções que exercem num dado contexto histórico, levando-se em conta as teorias ligadas à estética da recepção.

Não se trata, evidentemente, de uma valorização exagerada do contexto em detrimento das obras. Estas figuram em primeiro plano no livro de SCHMIDT-DENGLER Ohne Nostalgie (2002), em que um dos capítulos é intitulado "Prolegômenos para uma história social da literatura austríaca no período entre 1918 e 1938", com o que se situa no âmbito do projeto aqui apresentado. Programatica e coerentemente, os capítulos deste livro tratam ora de Viena, ora de obras literárias específicas, ora de temas como a importância da história, criando uma constelação que procura se incumbir desta tarefa tão complexa e interdependente (SCHMIDT-DENGLER 2002). Seu ponto forte está exatamente na perspectiva interdisciplinar, que leva em conta as teorias literárias mais atuais e faz um balanço das tentativas já realizadas ao longo do tempo, com grande ganho epistemológico tanto para a história quanto para a crítica e a teoria literárias. $\mathrm{O}$ projeto ainda está em andamento, tanto em sua realização quando nas discussões teóricas e práticas que continuamente repõe, mas este início é muito auspicioso.

Partindo dessas considerações, ambos realizam críticas severas ao modo como a maioria das histórias da literatura alemã produzidas na Alemanha analisa os autores 


\section{Flory, A. V. - Provocação formal em Heldenplatz}

austríacos. Para SchmidT-Dengler, a história austríaca é muito diversa da alemã ao menos a partir de 1806. As marcas históricas da literatura austríaca e sua importância são muito específicas, assim como os contextos nos quais estas literaturas surgem e estão inseridas. "Para oferecer um exemplo bem expressivo: os anos 1866, 1914, 1918, 1933, 1934, 1945 e 1955 têm para a história austríaca (...) e para a literatura austríaca uma função muito diversa do que têm na Alemanha" (SCHMIDT-DENGLER 1996: 12). ZEYRINGER é bem mais incisivo ao dizer que há uma espécie de "lenta anexação" cultural operada por algumas histórias da literatura alemã em relação aos autores austríacos, entendidos sem mais dentro da tradição alemã (ZEYRINGER 1999: 28).

Para tratar de casos específicos, tomemos a Deutsche Literaturgeschichte, organizada por Wolfgang Beutin et al., que passa, superficialmente, por alguns autores austríacos na seção Die Literatur der Bundesrepublik, escrita por Ralf Schnell. Autores como Ilse Aichinger, Ingeborg Bachmann, Peter Handke e Thomas Bernhard são citados, mas nenhum é estudado no contexto austríaco, que na maioria das vezes não é sequer mencionado (SCHNELL 2001: 630s). No capítulo Deutsche Literatur nach 1945, escrito pelo mesmo autor, apenas Peter Handke aparece, por conta do famoso episódio de sua participação da reunião do Grupo 47 em 1966, mas, de novo, a moldura se mantém em contexto alemão. Apenas autores com bom trânsito no mercado alemão foram lembrados. Embora os três primeiros autores acima citados tenham participado ativamente de instituições literárias alemãs, como o Grupo 47, e portanto seja compreensível que sejam analisados a partir da Alemanha (embora isso seja motivo para ressalvas, para dizer o mínimo), o mesmo não se dá com Thomas Bernhard, o que não impede que seja tratado como os outros.

ZEYRINGER (1999) escolhe para uma avaliação crítica mais detida a melhor, segundo ele, entre as histórias literárias alemãs ao estudar autores austríacos: a Geschichte der deutschen Literatur von 45 bis zum Gegenwart, organizada por Wilfried BARNER (1994) e escrita por muitos pesquisadores. Por ser a melhor dentre as obras concorrentes, Zeyringer considera que as críticas servirão de base também para as demais obras do mesmo gênero. ${ }^{6}$ Embora o livro organizado por Barner leve em conta o

\footnotetext{
${ }^{6}$ Seja dito de passagem que isso não inclui a obra ensaística ou as pesquisas específicas de autores alemães sobre a literatura austríaca, pois se restringe a um gênero bem específico, o da historiografia
} 


\section{Flory, A. V. - Provocação formal em Heldenplatz}

contexto austríaco para a análise das obras, ele se restringe aos autores que tiveram maior sucesso e repercussão na Alemanha. Não apresenta autores fundamentais para a literatura austríaca como Gerhard Fritsch (além de escritor, como vimos, foi editor de revistas importantes como Wort in der Zeit e Literatur und Kritik, sendo um nome central para o sistema literário austríaco) e Lernet-Holenia, figura decisiva para a compreensão do contexto austríaco no pós-1945, o que já foi visto. Esses autores, não obstante sua pouca relevância estética (no caso de Lernet-Holenia) e sua fraca divulgação e recepção no mercado alemão, são fundamentais para que se possa entender a obra dos autores que conquistaram espaço neste mercado, como Ilse Aichinger.

Deste modo, Barner fala do êxodo dos autores austríacos para a Alemanha e outros países, mas não discute suas causas, o que seria pressuposto imprescindível para uma história literária (ZEYRINGER 1999: 32-3). Quando estuda a peça Heldenplatz, de Thomas Bernhard, não cita em nenhum momento o contexto austríaco, chave para o tema, para a forma e para a recepção da peça, o que corrobora a leitura de Zeyringer. Inserindo o autor sem mais no âmbito da Nova Interioridade (Neue Innerlichkeit), limita muito sua avaliação, restringindo a obra a um solipsismo misantropo e autocentrado. (BARNER 1994: 633). “O que se conclui é que os autores austríacos não cabem no esquema de periodização estabelecida pela historiografia alemã (feita na Alemanha)" (SCHMIDT-DENGLER 1996: 14). A dificuldade do enquadramento se deve, em grande parte, a idiossincrasias históricas e sociais que são trabalhadas pelos temas e, sobretudo, pelas formas literárias, que não espelham esse processo social, mas o expressam e problematizam.

Em suma, vimos até aqui o questionamento e a problematização da historiografia literária em várias frentes e perspectivas. Em primeiro lugar, suas bases epistemológicas estão calcadas no historicismo, com neutralidade e objetividade forjadas que não fazem jus à literatura. Mesmo se escaparmos desses pressupostos, a história da literatura alemã não dá conta de compreender, em suas categorizações, uma literatura tão específica como a austríaca. Por fim, uma história literária eminentemente

literária. Um autor e professor alemão como Sebald, radicado na Inglaterra, escreve ensaios sobre literatura austríaca que não se encaixam nas objeções acima apresentadas. Cf. SEBALD 2006. 


\section{Flory, A. V. - Provocação formal em Heldenplatz}

austríaca não resolve a questão estabelecendo um cânone próprio, como se tentou forjar na Áustria do pós-1945.

Os projetos atuais, representados aqui por Schmidt-Dengler e por Zeyringer, começam pelo questionamento teórico das premissas epistemológicas para uma historiografia literária, com acerto, e relativizam assim seus métodos tradicionais, partindo para a análise e interpretação cerrada de obras inseridas em contextos determinados. A relação interna (imanente) entre texto e contexto é um aspecto dessas novas perspectivas. De certa maneira, estas já estão imbuídas da crítica a categorizações definitivas e bem-assentadas, optando pela abertura, e exigem um mergulho nas obras para ver ali como a história faz parte da constituição da forma artística, aproximando-se de uma crítica imanente da obra de arte.

\section{Literatura como historiografia inconsciente - o caso Heldenplatz}

Dessa forma, talvez seja mais produtivo estudar como a história está inscrita na obra de arte, deixando para um segundo momento as altercações com as histórias literárias nacionais e os movimentos estéticos, ou seja, com o plano macro. O ponto de fuga será a pertinência e alcance de se entender a literatura como Medium-de-reflexão benjaminiano que leve em conta a historicidade das formas literárias e a sua liberdade a partir do século XVIII, contribuindo para a construção de uma historiografia materialista pelo mergulho nas obras. E como a história é constitutiva para a literatura? Pelos seus materiais, sua linguagem, seus temas e, principalmente, por sua forma.

Os antagonismos não resolvidos da realidade retornam às obras de arte como os problemas imanentes da sua forma. É isto, e não a trama dos momentos objectivos, que define a relação da arte com a sociedade. (ADORNO 2008: 18)

A referência ao social não deve levar para fora da obra de arte, mas sim levar mais fundo para dentro dela. [...] Esse pensamento, porém, a interpretação social da lírica, como aliás de todas as obras de arte, não pode portanto ter em mira, sem mediação, a assim chamada posição social ou a inserção social dos interesses das obras ou até de seus autores. Tem de estabelecer, em vez disso, como o todo de uma sociedade, tomada como unidade em si mesma contraditória, aparece na obra de arte; mostrar em que a obra de arte lhe 


\section{Flory, A. V. - Provocação formal em Heldenplatz}

obedece e em que a ultrapassa. O procedimento tem de ser, conforme a linguagem da filosofia, imanente. (ADORNO 2003: 66-67)

O ponto de partida da assim chamada crítica imanente é a obra de arte, que não realiza um formalismo auto-suficiente, posto que investiga como a história penetra na mesma, ainda que de modo inconsciente. A arte não surge aqui como mero documento, o que a faria secundária em relação à história. Como diz Schwarz, a crítica no século XX atentou para "a incrível complexidade interna da literatura, da natureza protéica da forma, e, sobretudo, do papel decisivo dessa última.” (SCHWARZ 1999: 29)

Nosso percurso aqui parte do pressuposto de que não é suficiente ver a obra de arte na história: é preciso, ainda, perceber a história na obra de arte. O caso da última peça de teatro de Thomas Bernhard, Heldenplatz, escrita e encenada em 1988, funciona como a materialização desta assertiva: 50 anos depois da anexação nazista, os gritos de júbilo na 'Praça dos Heróis' soam ainda mais altos do que em 1938. A provocação direta realizada por esta asserção, central para a montagem em questão, também aponta para a repetição incansável presente em todas as obras de Bernhard, tanto em nível temático quanto linguístico. Há uma clara afinidade eletiva entre as continuidades acachapantes em Fasching e em Heldenplatz, ali em chave alegórica, aqui numa remissão direta à história austríaca recente.

A obra do austríaco Thomas Bernhard vem paulatinamente sendo alçada à condição de cânone literário na Europa. Já são muitos os que o consideram um clássico, com toda a carga, positiva e negativa, que tal estatuto carrega consigo. O arrefecimento de seu ímpeto crítico em relação à literatura e à sociedade passa pelo processo de canonização do homem público, tomado agora como um escritor excêntrico e atormentado, dono de uma sensibilidade aguçada e neo-romântica. Essa perspectiva empresta caráter subjetivo às questões espinhosas com que sua obra lidou e ainda lida. Esse é o contexto mais amplo de sua recepção hoje em dia, momento em que suas narrativas são traduzidas e publicadas no Brasil, nos últimos anos pela editora Companhia das Letras.

Curiosamente, nenhuma de suas muitas peças foi ainda publicada no Brasil, embora haja algumas montagens, como por exemplo No alvo, em 2004, e A força do hábito, em 2004, ambas em São Paulo, além de Ritter, Dene, Voss, em Porto Alegre e 


\section{Flory, A. V. - Provocação formal em Heldenplatz}

São Paulo, e mesmo a montagem de Árvores Abatidas, texto adaptado para teatro, em Curitiba, em 2009. Para fugir de uma leitura esteticizante de sua obra, é preciso nunca perder de vista o chão austríaco, sempre presente em suas obras, com ênfase cada vez maior a partir da escrita do primeiro volume autobiográfico, em 1975. O perigo que sua obra corre é recair em uma análise de influência pós-moderna, identificando a perda de sentido da linguagem e sua incapacidade de expressão num mundo em que tudo é fugidio, recaindo numa aporia niilista ou no gozo do texto, como artefato verbal. Cumpre lembrar que a obra de Bernhard se esquiva a essa leitura unidirecional de diversas maneiras, no teatro em especial, escrevendo sempre para seu público de estréia, ou melhor, contra ele, como bem formulou um crítico sagaz, que será comentado a seu tempo.

Nesta seção do artigo pretendo discorrer sobre alguns aspectos do teatro do austríaco Thomas Bernhard, mais especificamente sobre sua última peça, Praça dos Heróis (Heldenplatz), de 1988. Essa montagem foi marcada por um escândalo que, tudo leva a crer, era previsto pelo autor, talvez mesmo programado por ele. Isso se torna ainda mais instigante quando se sabe que a citação quase direta da realidade material, pelo tema, será contrastada, no âmbito da criação verbal, por uma escrita fragmentária, circular, a tal ponto que o autor chega a ser acusado de solipsista por sua linguagem labiríntica, hermética, repetitiva e cansativa, exagerada até o limite do aceitável.

Como articular essas duas perspectivas, em aparência mutuamente excludentes a saber, uma aproximação quase imediata com a matéria social na concepção de uma provocação direta e implacável, combinada com uma mediação exacerbada pela linguagem, que impede uma visada 'realista', no sentido de escola realista, exigindo a distância do público pela artificialidade e esteticização da linguagem? Quais os impactos e produtividade em termos formais? De que modo se constitui uma dialética entre forma literária e processo social a partir dessa encenação? Qual o modo pelo qual dialoga com a história das formas teatrais? São questões abrangentes e complexas que, aqui, serão antes apresentadas do que desenvolvidas em todas as suas potencialidades.

Algumas linhas sobre o enredo e estrutura da peça se afiguram como necessárias. O diretor alemão Claus Peyman, então superintendente do Burgtheater de Viena, o mais respeitado palco da Áustria, pede ao amigo e colaborador Bernhard uma 


\section{Flory, A. V. - Provocação formal em Heldenplatz}

peça para ser montada no jubileu de cem anos da fundação do teatro, 1988, coincidindo com os 50 anos da anexação nazista. Um grande circo estava sendo armado em torno destas comemorações, buscando repisar a velha tecla da vitimização da Áustria e dos austríacos. Os eventos procuravam, em especial, esquecer o escândalo da eleição de Kurt Waldheim, em 1986, para a presidência da Áustria, quando seu passado ligado às SS viera à tona e, não obstante isso (e talvez mesmo por causa disso) ganhara a eleição. Um momento em que a política austríaca muda radicalmente, nas palavras de vários críticos, ao se perceber que a remissão ao passado nazista (nas tropas SS, que exigiam alistamento voluntário e perpetravam os crimes mais hediondos) não impedia um político de ocupar uma das cadeiras mais importantes de seu sistema político (HASLINGER 2001; MENASSE 2005: 249s).

Com estréia em 4 de novembro de 1988, a peça Heldenplatz tem como espaço dramático o local onde, cinquenta anos atrás (exatamente no dia 15 de março) Hitler fora recebido com júbilo e festa pelos vienenses. Num apartamento diante desta praça (onde se situa, de fato, o Burgtheater, em que a peça foi encenada), a família e os amigos do prof. Josef Schuster, judeu autríaco, se reúnem para o enterro deste, que se suicidara após constatar que a situação da Áustria estaria pior agora (1988) do que cinquenta anos atrás, com os ex-nazistas saindo dos escuros para onde foram impelidos, voltando ao primeiro plano. A peça prescinde de conflitos intersubjetivos e de curva dramática ascendente, o que deixa a ação em segundo plano. Os personagens, das camareiras às filhas, irmãos e amigos, discutem a situação atual da Áustria ou questões banais, do dia-a-dia. O tema central, de fato, é a Áustria e sua história recente, assunto épico por excelência.

O momento no qual, ao final da peça, a esposa do prof. Schuster ouve (apenas ela e o público) a gravação original da recepção para lá de calorosa que Hitler recebera logo ali em frente, funciona como a materialização cabal dessa perspectiva épica, em chave crítica. São milhares de vozes em estado de êxtase e adoração, contrastando com o olhar vítreo da silenciosa Schuster. Os outros personagens não param de conversar, e a princípio ouve-se apenas um sussurro. Aos poucos, o volume aumenta e não se ouvem mais suas vozes, embora continuem conversando. Agora temos apenas Frau Schuster, imóvel, estarrecida, desfigurando-se aos poucos, e a voz da multidão, tomando conta da cena. Formalmente, o diálogo intersubjetivo perde importância e centralidade, embora 


\section{Flory, A. V. - Provocação formal em Heldenplatz}

ainda esteja presente, e a história é atualizada em 1988 cenicamente, evidenciando a afinidade eletiva com que um tempo histórico cita outro, ganha sentido num presente que o significa, na expressão do rosto de Frau Schuster, abrindo espaço para um 'agora da conhecibilidade' benjaminiano, aumentando a tensão e permitindo o irromper de significados sobre ambos os momentos.

A montagem faz as vezes do historiador materialista benjaminiano, que quer contar a história a contrapelo da voz dominante (BENJAMIN 1996). Seu efeito cênico é potencializado pelo escândalo público em torno da montagem. No fim da cena, Frau Schuster cai morta, com a cara na sopa. Em cena, as vozes que são a verdade da Áustria de 1938, agora audíveis e mais aterradoras nos idos de 1988. Nos porões da democracia austríaca e da união pela autonomia política, pouca coisa mudou; apenas na superfície, com a recriação de sua imagem como um povo bonachão e alegre, incapaz de cometer as atrocidades nazistas, colocando-se como a primeira vítima de Hitler. A remissão ao quadro político-social não poderia ser mais evidente. Bernhard, desse modo, incita o debate que se queria abafar. Waldheim em pessoa acusa a peça, dizendo: "Eu considero essa peça uma ofensa grosseira ao povo austríaco", ao que o autor responde: "Sim, minha peça é atroz. Mas a peça encenada diariamente em todos os cantos deste país é igualmente atroz" (BERNHARD 1988: contracapa).

A crítica teatral Sigrid Löffler consegue trechos da peça, vazados em meio aos ensaios, e os publica na revista Profil - o que, segundo muitos, teria ocorrido com a anuência implícita de Bernhard e Peyman - em agosto e setembro de 1988, dois meses antes da estréia, o que instaura um escândalo pelas invectivas dos personagens contra a Áustria e os austríacos, chamados ao longo da peça de débeis-mentais, nazistas e católicos, todos os seis milhões de habitantes (MiLlner 1995: 249s). Como se verá, esse caráter hiperbólico faz parte de sua estética, constituindo o que ele chamará de 'arte do exagero'. Jornais como o Neue Kronen Zeitung e políticos como o vice-chanceler Alois Mock, além do ex-chanceler Bruno Kreisky, posicionam-se contra a montagem da peça, enquanto a ministra da educação Hilde Hawlicek e autores do porte de Elfriede Jelinek, Michael Scharang e Peter Turrini defendem a liberdade de expressão.

No dia 12 de outubro de 1988, Alois Mock e o famigerado Jörg Haider exigem a demissão do diretor do Burgtheater, com as palavras: "Fora de Viena com a escória" 


\section{Flory, A. V. - Provocação formal em Heldenplatz}

(DitTMar 1993: 183), com o que miravam o alemão Peyman e parte de sua equipe. Surgem campanhas de difamação contra Peyman e Bernhard que, de certa forma, fazem com que o texto da peça seja atualizado, por assim dizer, no palco real da opinião pública austríaca, antes mesmo da encenação, conforme disse HöLLER (2001: 7): "De uma hora para outra havia esforços para o boicote da apresentação e se exigia a expulsão do autor e do diretor, como se o teatro tivesse conseguido provar a provocante asserção da peça, de que os anos de 1938 e 1988 seriam intercambiáveis."

\section{Do uso e do efeito das repetições em Bernhard}

Seguiremos agora para algumas breves considerações sobre a linguagem em Heldenplatz. As repetições, retomadas e voltas caracterizam toda sua obra e o tom de seus textos. Os efeitos são muito variados e, às vezes, até paradoxais. Num dos trecho da peça, característico de seu estilo, se lê:

\footnotetext{
O que os escritores escrevem / não é nada frente à realidade / simsim eles escrevem sim que tudo é amedrontador / que tudo é pervertido e decadente / que tudo é catastrófico / e que não há saída / mas tudo que eles escrevem / não é nada frente à realidade / a realidade é tão pior / que ela não pode ser descrita / ainda nenhum escritor a realidade / descreveu / como ela realmente é / isto é o mais amedrontador. (BERNHARD 1988: 115)
}

Aqui já podemos perceber alguns traços que vão permear sua escrita, em todos os seus romances e dramas, de uma maneira obstinada, e que funciona como uma espécie de provocação também contra o leitor. Em termos formais, não se trata de um poema dentro da peça, toda ela é escrita com frases curtas e, por vezes, por palavras isoladas, o que pode até ser lido como uma indicação cênica, embora não marcada como tal. A linguagem tenta apreender a realidade caracterizando-a como amedrontadora, assustadora, pervertida, decadente, catastrófica e sem saída, o que é repetido incansavelmente. No entanto, terrível mesmo é a impossibilidade de expressá-la pela linguagem, como ela é. No caso em questão temos escrevem, descrevem, escrevem; que tudo, que tudo, e que tudo, mas tudo; realidade, realidade, realmente, e por aí afora. São vários os efeitos desta repetição; em primeiro lugar, a repetição excessiva embaralha o sentido atribuído às palavras. A repetição sistemática nos leva também a 


\section{Flory, A. V. - Provocação formal em Heldenplatz}

questionar se o falante está realmente certo daquilo que diz: a assertividade e a objetividade costumam ser dadas apenas uma vez. Quem vacila, duvida, não se sente seguro repete, muda a entonação, a ordem sintática, dá voltas em torno do mesmo ponto sem parar, cisma. $\mathrm{O}$ cismador é aquele que nunca se considera pronto, aquele que acha que deve sempre voltar ao tema, buscar novas cores.

O mais importante, porém, é a falta de mobilidade que a repetição expressa. Se, no plano do conteúdo, 1938 e 1988 são aproximados em sua infâmia, essa identidade e permanência ganham contornos, em termos formais, pela repetição das mesmas ideias, vocábulos e estrutura sintática. Já se viu que a peça não é marcada nem pela ação e nem pelo diálogo, embora seja o texto o único recurso que resta aos personagens. Sua repetição dá contornos a esse falar contínuo sem alteração: repisa o mesmo, como se esses fossem os únicos assuntos que valessem a pena ser tratados. Desse modo, a linguagem não é, em Bernhard, desviante em direção ao esteticismo. Primeiro porque impede, pela repetição e exagero, que seja denotativa, mero instrumento de transmissão de mensagens. Segundo, mimetiza a imobilidade psicológica e social. Terceiro, pelas invectivas contra a Áustria e sua política sócio-cultural de encobrimento pela repressão de sua culpa e postura na guerra, fugindo de um estilo realista e, ainda, contando com tom provocador, atiçando a opinião pública. Sua incapacidade de descrever a realidade não recai em vale-tudo semântico, mas na crítica à cultura: a linguagem é social, por natureza, e não pode ser usada sem mais. Sendo assim, faz crítica da linguagem para torná-la produtiva e criativa para a compreensão da realidade. Desse modo, ela não se afasta da realidade, mas exige uma remissão dialética a ela, reforçando o papel ético da estética. Vale a pena discutir um pouco mais detidamente sua 'arte do exagero'.

\section{Arte do exagero e teor de verdade da mentira}

Comecemos por uma citação:

Prof. Robert: A Áustria não é nada além de um palco / no qual tudo é degradado e exterminado e degenerado / [...] / seis milhões e meio de débeis-mentais e desvairados / que urram ininterruptamente com toda a fúria por um diretor / O 


\section{Flory, A. V. - Provocação formal em Heldenplatz}

diretor virá / e os levará definitivamente ao abismo / seis milhões e meio de comparsas." (BERNHARD 1988: 89)

Aqui se abre o espaço para uma curta discussão sobre a forma da escrita artística, sem perder de vista sua inserção na sociedade, pois Bernard, como já se viu, só por erro pode ser rotulado como um autor fechado em si mesmo, preocupado apenas em realizar torneios linguísticos auto-referentes. A “arte do exagero" (Übertreibungskunst) é um dos pontos centrais de sua estética, levada em consideração por todos os seus comentadores. Ela encontra sua formulação mais acabada no romance Extinção, de 1986, que tem um diálogo muito frutífero com a peça em questão, especialmente no que tange à atualização do passado nazista na Áustria da década de 80, tanto pelo tema como pela concepção de linguagem que se depreende dos textos. No romance, lê-se a determinada altura: "Muitas vezes somos levados a tal ponto por um exagero [...] que acabamos por considerar este exagero como o único fato lógico e não percebemos mais o fato real, só o exagero levado desmedidamente ao extremo" (BERNHARD 2000: 447).

A realidade passa a ser então esse exagero, necessário para a expressão e criação de todo e qualquer fato. Mas que não se incorra em erro: o exagero não pode ter suas arestas aparadas para se chegar ao "fato" verdadeiro, em estado puro, intocado: este não existe, pois depende da linguagem, de uma forma, de uma expressão e de uma posição, tarefa da qual não podem fugir os artistas, em especial os escritores: “[...] tal como o escritor que não exagera é um escritor ruim, pode ocorrer também que a verdadeira arte do exagero consista em subentender tudo [...]" (BERNHARD 2000: 448).

O exagero na expressão não passa de uma diminuição ou, em outras palavras, de algo muito diferente da realidade social, visto que o material é outro: não há sangue no chão, mas tinta no papel, que aceita tudo. A mediação artística, mesmo quando utiliza as tintas mais negras, não chega perto do terror da realidade social que, por outro lado, cria e sustenta. A passagem citada em Heldenplatz é das mais significativas a este respeito. Nela a linguagem não pode exprimir a realidade, não apenas por ser outra coisa, mas ainda por ser a realidade muito pior do que qualquer expressão, mesmo a mais incisiva. Por trás dessa concepção está a impossibilidade da mimetização do real pela arte, o que implica numa necessária distorção pela mediação da linguagem e, ainda, pela perspectiva e pelos interesses de quem narra. A forma literária em que essa mentira será 


\section{Flory, A. V. - Provocação formal em Heldenplatz}

articulada fala uma verdade da forma social, também ela mediada. A Untertreibung pode ser lida como a insuficiência da arte e do sujeito em estabelecer a ponte que conduza à realidade, de modo que resulte num arrefecimento em relação à experiência social real; a ocultação disso consiste no maior dos perigos. Daí a necessidade do exagero que, no caso em questão, provoca o leitor e tenta, ao menos, estimulá-lo, retirálo da apatia típica do momento do consumo passivo das informações segundo o padrão em nossa sociedade.

\section{Provocação formal em Heldenplatz: politização da estética}

O exagero leva à provocação. Ao desenvolver esses temas tanto no conteúdo quanto na forma, criando um diálogo incessante e rico, com choques, reforços - nova repetição -, do qual surge uma estrutura. Isso tudo não seria tão vivo e forte, se a escrita de Bernhard fosse eminentemente metafísica e abstrata, o que não é definitivamente o caso: trata-se da Europa, da Áustria e sua cultura, história, espírito. Como bem notado por WiNKLER (2002: 100), Bernhard escreve contra seu público de estréia, o que não ocorre pela primeira vez, sendo antes um fator estrutural em muitas de suas peças. Isso exige a participação ativa do público, instigado a interagir. Fica evidente que a provocação se eleva à forma quando se compara com uma encenação dessa peça na França, que tenta ser fiel às palavras do texto, e não à forma, realizando assim uma crítica desabrida à Áustria. Sua verdadeira índole assoma ao primeiro plano pela única alteração introduzida por esta montagem: na passagem em que os socialistas são considerados colaboradores dos nazistas, sem especificação, a adaptação insere uma palavrinha: os socialistas austríacos teriam agido assim. Desse modo, os encenadores franceses evitam que se confunda esta montagem - que se queria estéril - à colaboração dos socialistas com o governo de Vichy, na França sob ocupação alemã. Entre eles, como se aventava, figurava o então primeiro-ministro Mitterand. Ou seja: a encenação funciona como um panfleto contra a Áustria, sem citar nem de longe o contexto francês. Isso difere muito do caso austríaco que, a despeito das oposições, foi encenada no Burgtheater, com todo o escândalo tanto dentro quanto fora do teatro. 


\section{Flory, A. V. - Provocação formal em Heldenplatz}

Como se viu, a obra de Thomas Bernhard nos anos 80 não é alheia ao quadro histórico em que está inserida. A politização da estética contra esse contexto será uma das linhas de força de sua obra. Por um lado, a altercação com a história recente austríaca, que deve ser relida a contrapelo, buscando justamente na linguagem e na memória o outro discurso, abafado, reprimido e esquecido: essa linha leva até aquela considerada sua obra-prima, Extinção. Por outro lado, uma provocação conseguida pela entrada quase direta da matéria social para dentro da obra de arte, por meio da palavra mediada: impureza na autonomia da obra de arte que está relacionada com a forma social que engendra a modernidade.

O autor não descuida em criticar o isolamento da arte como esfera autônoma da vida, cisão essa materializada em templos como o Burgtheater, que ele pretende dessacralizar. O palco do Burgtheater agora faz parte das conversas pelas ruas de Viena, e o escândalo faz parte deste cálculo. O Neue Kronen Zeitung, jornal conservador entre os mais importantes da Áustria, publica no dia da estréia uma fotomontagem do teatro em chamas, o que remonta ao fogo que destruiu o Burgtheater durante o austrofascismo. Peter Sichrovsky, então chefe de redação da seção Feuilleton do jornal Der Standart, publica no dia da estréia (4 de novembro de 1988) um artigo no qual pede não apenas boicote, mas tumulto em frente e dentro do teatro. Suas palavras são eloquentes:

\footnotetext{
Um escritor e diretor de teatro, que tem uma opinião inequívoca sobre esse país e vê seus moradores, de modo geral, como idiotas e criminosos, utiliza uma personagem [...] para transmitir essa mensagem ao público. Essa personagem é, para fazer justiça com os diversos jubileus deste ano, um judeu! O judeu, analítico e inteligente como (naturalmente) todos os judeus, se ocupa, na condição de imigrante que retornou ao país, dia e noite com a alma austríaca. [...] Aqui um diretor de teatro de Bochum, com a ajuda de um escritor austríaco, deixa um judeu de Viena latir como um pastor alemão. (BEIL et al 1999: 98)
}

Assim a peça e o texto conseguem uma amplitude importante para o cálculo de Bernhard; a peça vai às folhas policiais, políticas e econômicas, tendo em vista a crítica que recebe pelo fato desse teatro ser financiado com dinheiro público. Nesse sentido, a recepção e o efeito deixam de ser exteriores à obra, que conta com essa repercussão como parte de sua estratégia. "Hoje já se tornou difícil falar sobre a Áustria sem citar o nome Bernhard” (SCHMIDT-DENGLER 1997: 177). Sua ativa participação como figura 


\section{Flory, A. V. - Provocação formal em Heldenplatz}

pública contribui para a incursão da vida pulsante na obra. Uma montagem que não leve em conta esse aspecto não faz jus à peça, o que dá conta de seu caráter formal.

\section{Considerações finais}

No caso austríaco, escrever a história contra a corrente, salvando as leituras que foram abafadas por uma cultura que se firma e se confirma continuamente, equivale, também, a uma crítica da própria linguagem, já pesada como chumbo pelas cargas históricas que carrega, nem todas heroicas ou sequer dignas. Daí a necessidade da ruptura, que se vê tanto em um enredo sem ação como nos personagens paralisados, em estado aporético. Noutras palavras, será preciso negar a autonomia da obra de arte, o que se consegue por seu estilo fragmentário e repetitivo, entre outras coisas. Sua 'arte do exagero' também realiza esse percurso rumo a uma arte que não é espelho da realidade, mas a torna visível, por mais que seja irrepresentável. Daí a tão comentada escrita solipsista, que, por esse ângulo, é negação da concepção tradicional de obra de arte que se esgota em si mesma. Porque ela faz, em Bernhard, com que a arte se confronte com sua insuficiência em retratar qualquer real, o que afirma seu estatuto de criação, em chave metalinguística e, também, metateatral.

O exagero explícito, elevado à forma, é também a porta de entrada para a provocação, posto que a Áustria e os austríacos estão na alça de mira de suas invectivas, que não são justificadas, mas apenas apresentadas: Bernhard não é um moralista que espera fazer um julgamento, mas apresenta questões que, abertas como aparecem, cobram uma participação do leitor, mesmo que seja negativa. Nas palavras de um crítico: "A encenação do escândalo genuíno - que Bernhard tem em mente - segue outra lógica. Ela oferece à arte autônoma a possibilidade de entrar em contato com a realidade mais séria e perigosa" (EllRICH 2002: 180-1). Seu teatro é o lugar por excelência onde consegue realizar esse projeto, e Heldenplatz seu exemplo mais bem acabado, dadas as circunstâncias em que a obra é concebida, criada, ensaiada e encenada.

Deve-se notar que a crise da linguagem é cultural e está diretamente ligada às diversas crises do século XX, que atingiram, com muito vigor, a Áustria. Como no caso 


\section{Flory, A. V. - Provocação formal em Heldenplatz}

de Heldenplatz é quase impossível que se perca de vista a remissão ao contexto externo, que inclusive se imiscui na estrutura da obra e impede que se a tome como uma obra de arte orgânica; ao contrário, deve ser lida como fragmento, como arte alegórica (BÜRGER 2009); a análise dessa obra serve como antídoto às correntes esteticizantes, exigindo uma leitura materialista que não exclui, pelo contrário, o estudo da linguagem. Neste sentido, sua dramaticidade está tanto no palco como fora dele.

A história pregressa não é apenas uma lembrança ruim para os autores que importam a partir do final da década de 60 , mas torna-se viva e irrompe por trás de uma linguagem algo hermética, dificilmente fluida, em geral emperrada, refreada, interrompida, mas que por vezes aflui à superfície. Essa linguagem não é um instrumento para a elaboração de um discurso racional, que é colocado em questão; ela é justamente vista como o depositório inconsciente dos valores culturais, e contar uma história com início, meio e fim pode ser mesmo um ato estético-político reacionário. Daí a afirmação de Bernhard de que é um destruidor de histórias, onde a história pode ser tanto a ficcional quanto a social. A história só existe como escrita da história, e carece de uma nova linguagem, para fazer o acerto de contas consigo mesma. A reescrita da história passa pela crítica da linguagem, e esse campo é preferencialmente da literatura, mais que dos historiadores, embora também o seja, em menor grau.

O historiador dificilmente escapa de conceitos que, para não perder o estatuto científico, dependem de uma lógica quase implacável, de uma coerência e universalidade que deixa pouco espaço para uma linguagem renovada, especialmente se não se leva em conta a vida dos conceitos, concebidos em movimento. Sua realização por meio de novos conceitos pode e deve ser realizada, mas repõe a questão em novas bases, posto que a função metalinguística depende de equivalências que, novamente, reforçam a concepção da linguagem como sistema (NUNES 1999). No caso da literatura essa questão ganha contornos próprios.

Muito ao contrário da historiografia, os romancistas tentam com isso assegurar nova autenticidade às suas composições ficcionais da história recente. Divergindo de uma historiografia social que, por exemplo, trabalha sobretudo analiticamente, eles não podem renunciar a pessoas de carne e osso. Mas ao expor de forma radical a subjetividade da perspectiva pessoal, ganham uma nova verdade. Eles demonstram a refração necessária - e porventura múltipla e subjetiva - na conversão de notícias do passado e, ao mesmo tempo, facilitam o 


\section{Flory, A. V. - Provocação formal em Heldenplatz}

processo dessa conversão ao fazer com que o passado se reproduza preponderantemente em cima de testemunhos linguísticos legados. (LÄMMERT 1995: 303)

A literatura é concebida aqui como uma escrita da história, não na condição de documento (que é externo e a subordina à história), mas como forma (que é interna e a relaciona com a história). Ela também não coloca os literatos no lugar dos historiadores, mas os insere numa dialética que aprofunda ambos os lados, que contribui para a busca da mediação entre o processo social e forma literária. Essa problematização almeja o teor de verdade (literária e histórica) na dialética entre a subjetividade da literatura (que tem na forma seu substrato objetivo) e a objetividade da escrita da história (que tem sua subjetividade na perspectiva de onde se fala). Nessa abordagem, não se trata tanto de historiografia literária, mas da epistemologia da escrita da história, no caso, literária. Noutras palavras, toma-se a acepção da literatura como historiografia, onde não se separam escrita da história e escrita da literatura ou, em outras palavras, entre escrita documental e ficcional, pois ambas almejam a autenticidade e a verdade por formas e procedimentos diversos, mas convergentes.

Um livro como Extinção, do mesmo Bernhard, pretende ser uma extinção criadora do personagem e da história austríaca, feita exatamente pela e na linguagem, visto que tanto o personagem e a história, como discutido ao longo do romance, só existem como linguagem. Essa questão também surge em Heldenplatz. Daí uma literatura que pretende, com sua escrita, aniquilar-se, extinguir seu próprio discurso, realizar o percurso de uma outra história, uma outra escrita da história, que dê voz aos que não tem voz, aos alijados das estruturas de poder e da sociedade.

Segundo Benjamin, a história não se faz pelo preenchimento dos vazios de um tempo homogêneo e sempre igual, mas pelo irrompimento e ressiginificação do passado num presente repleto, criando condições para a reflexão em um "agora da conhecibilidade", quando um tempo cita outro. Na peça, o ano de 1938 explode em 1988, com sinal trocado: os austríacos não são mais as primeiras vítimas de Hitler, mas seus seguidores fanáticos. Isso está em consonância com os debates em torno da eleição de Waldheim, e Bernhard toca na ferida. A reescrita da história começa no texto como literatura dramática, passa pelo espetáculo apresentado no Burgtheater, com ovações e 


\title{
Flory, A. V. - Provocação formal em Heldenplatz
}

xingamentos, e chega às ruas, rompendo com os limites estreitos que relega a arte aos teatros e às bibliotecas, fazendo dela o ponto de partida para uma revisão histórica.

Numa palavra, aqui a obra de arte (e sua recepção) são o lugar por excelência do historiador materialista benjaminiano, que quer juntar os cacos da história da destruição que marca todo documento cultural, e a partir desses cacos propiciar uma nova constelação de fragmentos que permita novas leituras e escritas da história.

\begin{abstract}
O caráter destrutivo conhece apenas uma divisa: criar espaço; conhece apenas uma atividade: abrir caminho. [...] O caráter destrutivo se alinha na frente de combate dos tradicionalistas. Uns transmitem as coisas na medida em que as tornam intocáveis e as conservam; outros transmitem as situações na medida em que as tornam palpáveis e as liquidam. Estes são chamados destrutivos. (BENJAMIN 1986: 187)
\end{abstract}

Em Bernhard, a literatura se faz historiografia inconsciente, ao expressar novas relações entre arte e literatura, entre o papel do autor e do público na construção da história - não os aceita mais como mero espectadores passivos -, pela dissolução e extinção de uma posição clara dos narradores e personagens, de um modo que a história dificilmente alcançaria, com a distância que é forma para certa escrita acadêmica. Em primeiro lugar, pela participação do autor no espaço público, como um personagem de seus textos. Em segundo lugar, pela forma da provocação e pelo estatuto da linguagem e da construção dos personagens, no âmbito da composição. Ainda pela recepção de sua obra e pela história dessa recepção. Por fim, resta o perigo que a crítica mais aguda anteviu e agora vislumbra: com sua morte, em 1989, e sua elevação ao estatuto de clássico contemporâneo, quase um porta-voz da Áustria, seu 'caráter destrutivo' se domestica, suas invectivas são perdoadas como fruto de uma mente embora genial e temperamental, também atormentada. A ascensão ao cânone é, hoje, o maior perigo que sua obra corre, e a (nova) historiografia literária não pode deixar de considerar esse processo como uma violência desmedida, como um momento da assertiva benjaminiana que diz que todo documento de cultura é também um documento de barbárie.

Assim fica especificado o sentido da asserção de Peter Handke já vista: os anos 80 na Áustria não entrarão para a história como a Era Waldheim, mas como Era Bernhard - trata-se de uma outra escrita da história, com seu próprio teor de conhecimento e verdade. 


\section{Flory, A. V. - Provocação formal em Heldenplatz}

\section{Referências bibliográficas}

Adorno, Theodor W. Notas de literatura I. Trad. Jorge de Almeida. Coleção Espírito Crítico. São Paulo: Duas Cidades / Editora 34, 2003.

. Teoria estética. Trad. Artur Morão. Lisboa: Edições 70, 2008.

AUCKENTHALER, Karlheinz F. Zeitschrift Österreich in Geschichte und Literatur (mit Geographie), n 38, Caderno 3, ano 1994.

BACHMANN, Ingeborg. Das dreißigste Jahr. In: Sämtliche Erzählungen. München: Pipper Verlag, 2005.

BARNER, Wilfried. (Hrg) Geschichte der deutschen Literatur von 1945 bis zur Gegenwart. München: C. H. Beck Verlag, 1994.

BAYER, Wolfram (org). Kontinent Bernhard: zur Thomas-Bernhard-Rezeption in Europa. Wien/ Köln/ Weimar: Böhlau, 1995.

BEIL, Hermann; et al. (Hgs). Weltkomödie Österreich. 13 Jahre Burgtheater 1986-1999. Wien: Zsolnay Verlag, 1999.

Benjamin, Walter. Obras escolhidas vol. 1. São Paulo: Brasiliense, 1996.

. O caráter destrutivo. In: Documentos de cultura, documentos de barbárie: escritos escolhidos. Trad. Ruth Mayer. São Paulo: Cultrix: EDUSP, 1986: 187188.

BERNHARD, Thomas. Heldenplatz. Frankfurt am Main: Suhrkamp Verlag, 1988.

Auslöschung. Ein Zerfall. Frankfurt am Main: Suhrkamp Verlag, 1986.

. Extinção. Tradução de José Marcos Mariani de Macedo. São Paulo: Companhia das Letras , 2000.

Berger, Albert. Der tote Dichter und sein Professor: Weinheber und Nadler in der Diskussion nach 1945. In: SCHMIDT-DENGLER, Wendelin; et al. (Hgs) Konflikte - Skandale - Dichterfehden in der österreichischen Literatur. Berlin: Erich Schmidt, 1995: 191-201.

BÜrger, Peter. Teoria da vanguarda. Trad. de José Pedro Antunes. São Paulo: Cosac Naify, 2008.

Cevasco, Maria Elisa. Dez lições sobre estudos culturais. SP: Boitempo, 2003.

DITTMAR, Jens. (Hg) Sehr Gescherte Reaktion: Leserbrief-Schlachten um Thomas Bernhard. Wien: Edition S, 1993.

ELLRICH, L. Die Tragikomödie des Skandals. In: SHÖßLER, F.; VILlingER, I. (Hrgs) Politik und Medien bei Thomas Bernhard. Würzburg: Königshausen und Neumann, 2002: 180-181.

FRITSCH, Gerhard. Fasching. Frankfurt am Main: Suhrkamp, 1995.

GREINER, Ulrich. Der Tod des Nachsommers: Aufsätze, Porträts, Kritiken zur österreichischen Gegenwartsliteratur. München: Hanser, 1979.

HASLINGER, Josef. Politik der Gefühle. Ein Essay über Österreich. 2. ed. Frankfurt am Main: Fischer Verlag, 2001.

HöLLER, Hans. Thomas Bernhard. Reinbeck bei Hamburg: Rowohlt, 2001.

INNERHOFER, Roland. GAV contra PEN. Die Institutionalisierung einer Spaltung. In: 


\section{Flory, A. V. - Provocação formal em Heldenplatz}

Schmidt-Dengler, Wendelin; et al. (Hgs) Konflikte - Skandale - Dichterfehden in der österreichischen Literatur. Berlin: Erich Schmidt, 1995: 225-235.

JAUSS, Hans Robert. A história da literatura como provocação à teoria literária. Trad. de Sérgio Tellaroli. São Paulo: Editora Ática, 1994.

LÄMMERT, Eberhard. História é um esboço: a nova autenticidade narrativa na historiografia e no romance. Trad. de Marcus Mazzari. In: Estudos Avançados n. 23. Revista do Instituto de Estudos Avançados da USP, 1995: 289-308.

LANDA, Jutta. Realistisch oder experimentell. In: SCHMIDT-DENGLER, Wendelin; et al. (Hgs) Konflikte - Skandale - Dichterfehden in der österreichischen Literatur. Berlin: Erich Schmidt, 1995: 215-224.

MAGRIS, Claudio. Der habsburgische Mythos in der Österreichischen Literatur. 2.ed. Salzburg: Otto Müller Verlag 1988 (1. ed. 1966).

MenAsse, Robert. Das war Österreich. Gesammelte Essays zum Land ohne Eigenschaften. Frankfurt am Main: Suhrkamp, 2005.

MiLlNER, Alexandra. Theater um das Burgtheater. Eine kleine Skandalogie. In: Schmidt-Dengler, Wendelin; et al. (Hgs) Konflikte - Skandale - Dichterfehden in der österreichischen Literatur. Berlin: Erich Schmidt, 1995: 248-266.

NADLER, Josef. Literaturgeschichte des deutschen Volkes. Dichtung und Schrifttum der deutschen Stämme und Landschaften. Berlin: Propyläem, 1941.

Literaturgeschichte Österreichs. Salzburg: 1951.

NunES, Benedito. Crivo de papel. 3a ed. SP: Ática, 1999.

SCHMIDT-DENGLER, Wendelin. Bruchlinien. Vorlesungen zur österreichischen Literatur 1945 bis 1990. Salzburg und Wien: Residenz Verlag, 1996.

. Der Übertreibungskünstler: zu Thomas Bernhard. Wien: Sonderzahl, 1997.

. Ohne Nostalgie: zur österreichischen Literatur der Zwischenkriegszeit. Wien: Böhlau, 2002.

SCHMIDT-DENGLER, Wendelin; ZEYRINGER, Klaus. Literaturgeschichte Österreichs. Eine Einführung in die Problematik. In: SchMidT-Dengler et al. (Hrgs) Literaturgeschichte: Österreich: Prolegomena und Fallstudien. Berlin: Erich Schmidt, 1995: 9-18.

SCHNELL, Ralf. Die Literatur der Bundesrepublik. In: Beutin, Wolfgang; et al. (Hgs). Deutsche Literaturgeschichte: von den Anfängen bis zur Gegenwart. Stuttgart / Weimar: Metzler, 2001, p. 580-659.

SCHWARZ, Roberto. Sequências Brasileiras. São Paulo: Cia das Letras, 1999.

SEBALD, W. G. Die Beschreibung des Unglücks: zur österreichischen Literatur von Stifter bis Handke. 5 ed. Frankfurt am Main: Fischer Verlag, 2006. (1. ed. 1994)

STEININGER, Rolf. Stationen auf dem Weg zum 'Anschluß'. In: GeHLER, M.; STEININGER, R.(Hrgs) Österreich im 20 Jahrhundert. Wien: Böhlau, 1997: 99152.

WEBER, Norbert. Das gesellschaftlich Vermittelte der Romane österreichischer Schriftsteller seit 1970. Frankfurt am Main / Berlin: Peter Lang, 1980. 


\section{Flory, A. V. - Provocação formal em Heldenplatz}

WILDGANS, Anton. Rede über Österreich. Disponível em: <http://www.antonwildgans.at/page87.html> (17/11/2010) Escrito em 1929.

WINKLER, J.-M. Rezeption und/oder Interpretation. In: HUBER, Martin; SCHMIDTDENGLER, Wendelin (Hrgs) Wissenschaft als Finsternis: Jahrbuch der ThomasBernhard-Privatstiftung. Wien/Köln/Weimar: Böhlau, 2002: 95-108.

ZEYRINGER, Klaus. Innerlichkeit und Öffentlichkeit: österreichische Literatur der achtziger Jahre. Tübingen: Francke, 1992.

Österreichische Literatur 1945-1998: Überblicke, Einschnitte, Wegmarken. Innsbruck: Haymon-Verlag, 1999.

Recebido em 01/10/2010

Aprovado em 13/10/2010 